\title{
Increase in uterine peroxidase activity in the rat uterus during oestrogen hyperaemia
}

\author{
D. B. Farley ${ }^{1}$, S. P. Ford ${ }^{2}$ and J. P. N. Rosazza ${ }^{3}$ \\ ${ }^{1}$ Department of Obstetrics and Gynecology, University of Iowa, Iowa City, IA 52242, USA; \\ ${ }^{2}$ Department of Animal Science, Iowa State University, Ames, IA 50011, USA; and \\ ${ }^{3}$ Department of Medicinal Chemistry, University of Iowa, Iowa City, IA 52242, USA
}

\begin{abstract}
Summary. The administration of oestrogen results in increased arterial blood flow in all mammalian species studied to date, but its mechanism of action has not been elucidated. Because an interval of $30-60 \mathrm{~min}$ is observed between oestrogen injection and uterine hyperaemia, it has been suggested that a vasoactive intermediate is involved and recent evidence suggests that catechol oestrogens are the vasoactive oestrogen intermediates. Uterine peroxidase catalyses the conversion of oestrogens to their catechol forms and thus may play an important role in oestrogen-induced uterine hyperaemia. The present studies evaluated the time course and dose-response effects of oestrogen on uterine peroxidase activity and related these to changes in uterine blood volume, an index of uterine hyperaemia in immature rats. These data demonstrated that the minimal effective hyperaemic dose of oestradiol also increased $(P<0.05)$ uterine peroxidase activity. The oestradiol-induced increase in uterine peroxidase activity preceded significant increases in uterine blood volume ( $1 \mathrm{~h}$ versus $2 \mathrm{~h}$, respectively). These data are consistent with a role for peroxidase-mediated conversion of oestradiol to catechol oestradiol in facilitating uterine hyperaemia in rats.
\end{abstract}

Kelwords: peroxidase; uterus; oestrogen; hyperaemia; rat

\section{Introduction}

Exposure of rat uterine tissue to exogenous oestrogen results in a marked increase in peroxidase activity (Lucas et al., 1955; Klebanoff, 1965; Jellinck \& Lyttle, 1972; Anderson et al., 1975; Lyttle \& DeSombre, 1977). Oestrogen-induced peroxidase activity of uterine tissues is mainly associated with subcellular microsomal particles (Lyttle \& Jellinck, 1976; Hosoya \& Saito, 1981). However, uterine fluid of oestrogen-primed rats also contains a soluble peroxidase (Klebanoff \& Smith, 1970; Hosoya \& Saito, 1981). Others have noted that a portion of eosinophil-stimulated uterine peroxidase activity occurs in the soluble fraction (Lyttle et al., 1989). Peroxidases catalyse the conversion of oestrogens to their catechol forms (Jellinck et al., 1985; Mondschein et al., 1986; Ball \& Knuppen, 1990). Catechol oestrogens may be mediators of oestrogen-induced uterine hyperaemia (Van Orden et al., 1986; Ford, 1989; Rosazza et al., 1989). Thus, peroxidases may play an important role in the early vascular response to oestrogen.

Although peroxidase is a major oestrogen-regulated secretory protein of uterine epithelium (Jellinck \& Newcombe, 1980), peroxidase activity has never been detected in uterine extracts earlier than $4 \mathrm{~h}$ after oestrogen exposure (Lyttle \& DeSombre, 1977). In these reports, guaiacol was used to measure peroxidase activity; the poor sensitivity of this reagent in peroxidase assays probably precluded earlier detection of increased enzyme titres.

The present study uses the much more sensitive, ortho-phenylenediamine assay (Gallati \& Brodbeck, 1982) to evaluate peroxidase activities in extracts of uteri taken from immature rats given 
low doses of oestradiol and to determine whether peroxidase activity is related to the extent of uterine hyperaemia. In addition, we report a substantial quantity of oestrogen-dependent peroxidase activity in the soluble fraction of uterine homogenates.

\section{Materials and Methods}

\section{Animals and treatments}

Immature female Sprague-Dawley rats weighing $35-45 \mathrm{~g}$ were obtained from Harlan Laboratories (Madison, WI, USA) at 21 days of age and used in all experiments. Thirty-eight rats were assigned to the dose-response experiment, 36 rats were used for the time course experiment and 35 rats were used for a third experiment designed to study the distribution of uterine peroxidase activity at $2 \mathrm{~h}$ and $20 \mathrm{~h}$ after oestradiol.

A stock solution of oestradiol (Sigma Chemical, St Louis, Mo, USA) was prepared in $95 \%$ ethanol $\left(1 \mathrm{mg} \mathrm{ml}^{-1}\right)$. Immediately before the dose response study, appropriate amounts of this stock solution were diluted with phosphatebuffered saline (PBS), pH 7.4, to make solutions for intravenous injection. The vehicle control consisted of PBS containing $0 \cdot 1 \%$ ethanol. Each rat was weighed, then lightly anaesthetized with ether. The deep femoral vein was exposed and the selected dose of oestradiol or the vehicle was administered into the vein in a volume of $0.1 \mathrm{ml}$ per $40 \mathrm{~g}$ body weight. The wound was closed with a wound clip and the animal allowed to regain consciousness. In the time course experiment, subcutaneous injections were used and the vehicle control consisted of $50 \%$ ethanol. A dose of $100 \mu \mathrm{g} \mathrm{kg}^{-1}$ body weight was used for subcutaneous injections to assure delivery of at least $1 \mu \mathrm{g}$ oestradiol kg $\mathrm{kg}^{-1}$ body weight to the bloodstream. Intravenous administration of oestrogen in the dose-response experiment was chosen to assure consistent delivery of the oestrogen doses, whereas subcutaneous administration was chosen for the time course experiment to avoid the known effects of stress on delaying uterine hyperaemia.

\section{Determination of uterine blood volume}

In the dose--response experiment, uterine blood volume was determined $2 \mathrm{~h}$ after oestrogen injection, whereas in the time course experiment uterine blood volume was determined 1,2 and $3 \mathrm{~h}$ after oestrogen injection. All animals were lightly anaesthetized with ether and a skin incision was made to expose the deep femoral vein. Each rat was given $10 \mu \mathrm{Ci}^{125} \mathrm{I}$-labelled human serum albumin (in a volume of $0.1 \mathrm{ml}$ ) into the deep femoral vein using a $1 \mathrm{ml}$ syringe and a 30 gauge needle. After equilibration for $5 \mathrm{~min}$, the rats had regained consciousness and were killed by cervical dislocation. An abdominal incision was made and blood was obtained from the descending aorta. Aliquots of $100 \mu \mathrm{l}$ were taken for measurement of radioactivity in a scintillation counter. The uterus and attached parametrium were excised and blotted to remove adherent blood from the surface. The tissue was weighed, then placed in $1 \mathrm{ml}$ cold saline for measurement of radioactivity. The tissue was then frozen in liquid nitrogen for subsequent determination of peroxidase activity. The uterine blood volume was calculated using the formula:

$$
\mu \mathrm{l} \text { blood } \mathrm{g}^{-1} \text { tissue }=\frac{\text { c.p.m. } \mathrm{g}^{-1} \text { tissue }}{\text { c.p.m. in } 1000 \mu \mathrm{l} \text { blood }}
$$

\section{Extraction of uterine peroxidase}

Uterine horns from individual rats were frozen in liquid nitrogen and pulverized to a fine powder and subsequently homogenized in $1 \mathrm{ml}$ of ice-cold Tris- $\mathrm{HCl}(\mathrm{pH} 7.2)$ using a Polytron homogenizer PT 10/35 fitted with a PTA 7 generator (Brinkmann Instruments, Inc., Westbury, NY, USA). Homogenates were centrifuged (Beckman, Model $\mathrm{L} 7-55 \mathrm{R}$ ) at $40000 \mathrm{~g}$ for $30 \mathrm{~min}$ at $4^{\circ} \mathrm{C}$; the $40000 \mathrm{~g}$ supernatant represented the soluble fraction. Pellets were rehomogenized in $\mathrm{lml}$ ice-cold Tris- $\mathrm{HCl}(\mathrm{pH} 7.2)$ containing $0.5 \mathrm{~mol} \mathrm{CaCl} \mathrm{I}^{-1}$ to solubilize the peroxidase present in the particulate fraction and centrifuged at $100000 \mathrm{~g}$ for $30 \mathrm{~min}$ at $4^{\circ} \mathrm{C}$. The $100000 \mathrm{~g}$ supernatant represented the $\mathrm{Ca}^{2+}$-extracted fraction.

\section{Ortho-phenylenediamine assay of peroxidase activity}

Peroxidase activity was determined by using the substrates $\mathrm{H}_{2} \mathrm{O}_{2}$ and $o$-phenylenediamine (Gallati \& Brodbeck, 1982). The reaction mixture $(1 \mathrm{ml})$ contained $650 \mu \mathrm{l}$ of $154 \mathrm{mmol}$ sodium citrate $1^{-1}$ buffer, $\mathrm{pH} 5.0,200 \mu \mathrm{l} o$ phenylenediamine solution $\left(75 \mathrm{mmol} \mathrm{l}^{-1}\right), 50 \mu \mathrm{H}_{2} \mathrm{O}_{2}\left(100 \mathrm{mmol}^{-1}\right)$ and $100 \mu$ l of uterine enzyme extract. Soluble and $\mathrm{Ca}^{2+}$-extracted fractions were adjusted to $0.25 \mathrm{~mol} \mathrm{CaCl}_{2} \mathrm{I}^{-1}$ immediately before assay. Higher concentrations of $\mathrm{CaCl}_{2}$ reduced the colour intensity of the reaction. It was necessary to prepare $0.75 \mathrm{mmol} o$-phenylenediamine $1^{-1}$ solutions in light-protected vials by adding $o$-phenylenediamine dihydrochloride tablets (Sigma Chemical Co., St Louis, MO, USA) to HPLC-grade water and to use the solution within 5 min of preparation. Reaction mixtures were vortexed and incubated at $25^{\circ} \mathrm{C}$ for $30 \mathrm{~min}$ and the reaction was stopped by the addition of $1 \mathrm{ml}$ of $2 \mathrm{M} \mathrm{HCl}$. The absorbance was then determined at $496 \mathrm{~nm}$ using a DU-64 spectrophotometer (Beckman Instruments, Fullerton, CA, USA) and the 
enzyme activity determined from a standard curve obtained with horseradish peroxidase. The tissue extract prepared from each rat uterus was assayed in duplicate at three dilutions. A laboratory extract pool was also assayed with each experiment to assess interassay reproducibility and parallelism to the horseradish peroxidase standard (Fig. 1). Results are expressed as pg horseradish peroxidase equivalents per $\mathrm{mg}$ of uterine tissue wet weight.

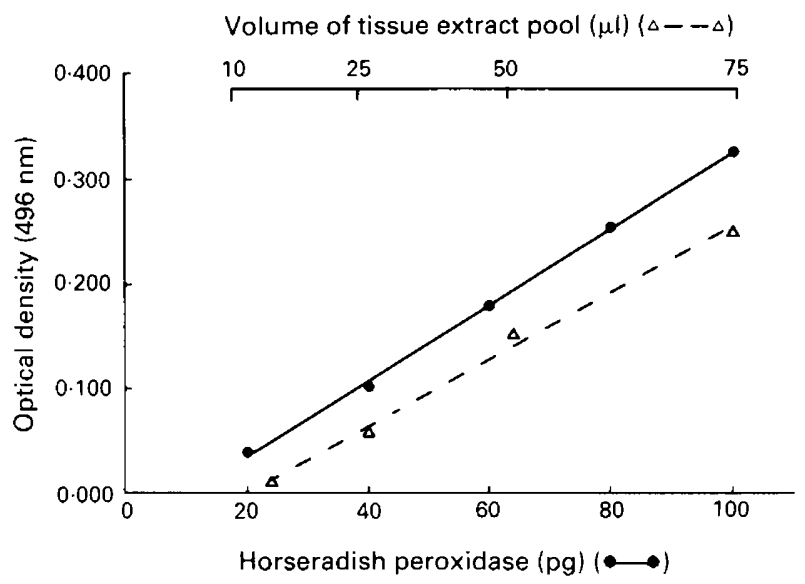

Fig. 1. Linearity of the $o$-phenylenediamine assay comparing five dilutions of horseradish peroxidase with dilutions of tissue extract.

\section{Statistical analyses}

Regression analysis was used to determine the dose-response relationship between oestradiol and uterine blood volume and between oestradiol and peroxidase. Analysis of variance was used to test which doses had associated mean responses that differed from one another.

\section{Results}

The lowest dose of oestradiol administered $\left(0.5 \mu \mathrm{g} \mathrm{kg}^{-1}\right.$ body weight $)$ produced a significant $(P<0.05)$ increase in uterine blood volume (Fig. 2$) ; 1 \mu \mathrm{g} \mathrm{kg}^{-1}$ body weight produced a greater $(P<0.05)$ increase in uterine blood volume than the $0.5 \mu \mathrm{g} \mathrm{kg}^{-1}$ body weight dose but higher doses of oestradiol (up to $100 \mu \mathrm{g} \mathrm{kg}{ }^{-1}$ body weight) failed to produce any greater increase in uterine blood volume. Uterine blood volume was not altered in animals injected with vehicle (data not shown). Uterine blood volume remained unchanged for $1 \mathrm{~h}$ after oestradiol injection and then increased $(P<0.01)$ at 2 and $3 \mathrm{~h}$ (Fig. 3).

As was the case for the uterine blood volume responses, the lowest dose of oestradiol that produced a significant $(P<0.05)$ increase in uterine peroxidase activity in the $\mathrm{Ca}^{2+}$-extracted fraction was $0.5 \mu \mathrm{g} \mathrm{kg}^{-1}$ (Fig. 4). Uterine peroxidase activities at doses of oestradiol from $0.5-$ $5 \mu \mathrm{g} \mathrm{kg}^{-1}$ body weight were positively correlated $(P<0.05, r=0.79)$ with the uterine blood volume.

Uterine peroxidase induction was observed during the time course of uterine hyperaemia (Fig. 5). Peroxidase activity $\left(11.5 \pm 1.8 \mathrm{pg} \mathrm{mg}^{-1}\right)$ was detected in the $\mathrm{CaCl}_{2}$ extract of individual uteri harvested from untreated control animals. Furthermore, oestrogen treatment produced a significant $(P<0.05)$ increase in enzyme activity as early as $1 \mathrm{~h}$ with no further increase observed at 2 and $3 \mathrm{~h}$.

Oestradiol treatment $\left(100 \mu \mathrm{g} \mathrm{kg}^{-1}\right.$ body weight) not only increased the $\mathrm{Ca}^{2+}$-extracted peroxidase activity but also increased the level of soluble peroxidase activity (Fig. 6). The amount of peroxidase activity in the soluble fraction was two to three times greater than that observed in the $\mathrm{Ca}^{2+}$-extracted fraction. At $20 \mathrm{~h}$, oestrogen exposure increased the $\mathrm{Ca}^{2+}$-extracted peroxidase 


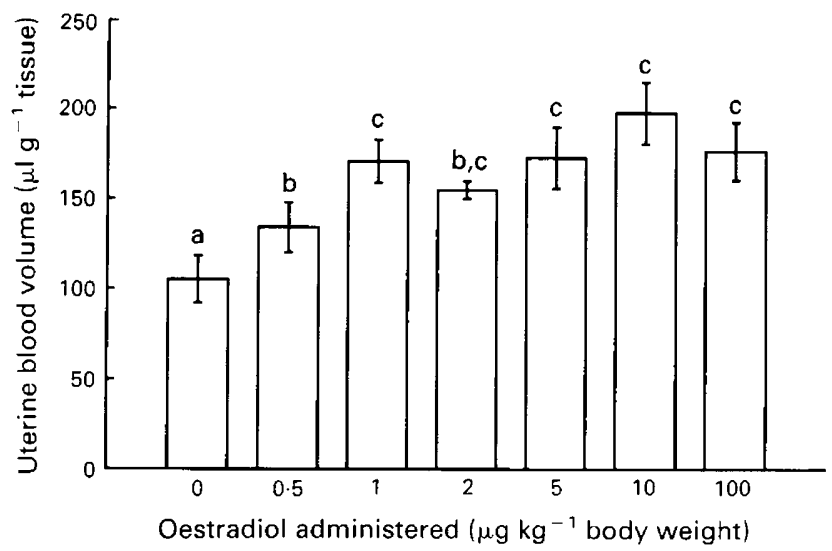

Fig. 2. Uterine blood volume response to vehicle $(n=6)$ or the indicated quantities of oestradiol $(n=4-6)$. Uterine blood volume was measured using ${ }^{125}$ I-labelled albumin $2 \mathrm{~h}$ after i.v. administration to immature rats. a,b,c Means ( \pm SEM) with different letters are significantly different $(P<0.05)$.

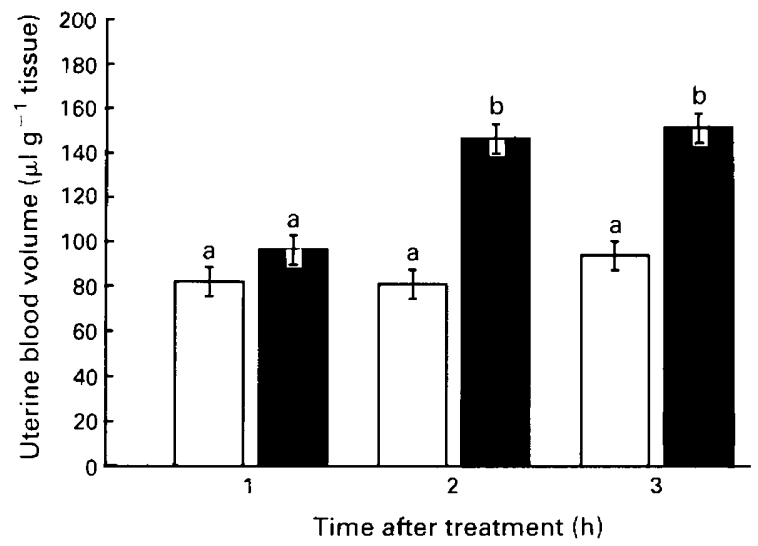

Fig. 3. Uterine blood volume response to vehicle $(\square)$ or $100 \mu \mathrm{g} \mathrm{kg}^{-1}$ body weight oestradiol (ם) at three time points after s.c. administration to immature rats (six animals per time point). Within a treatment, means $( \pm \operatorname{SEM})$ with different letters $(a, b)$ are significantly different $(P<0 \cdot 01)$.

activity in comparison with the $2 \mathrm{~h}$ exposure. During the same time, levels of soluble peroxidase remained constant.

\section{Discussion}

Oestrogen administration has previously been shown to increase activity of peroxidase in the uterus considerably with maximal activity appearing 20-24 h after a single injection (DeSombre, 1984). This study showed for the first time that oestrogen also increases uterine peroxidase activity before this, within 1-3 $\mathrm{h}$ after injection. These data also demonstrate that the lowest dose of oestrogen that increases uterine peroxidase $\left(0.5 \mu \mathrm{g} \mathrm{kg}^{-1}\right.$ body weight) is one-fifth the effective dose reported by others (Lyttle \& DeSombre, 1977). The picogram range of sensitivity observed with the $o$-phenylenediamine assay allowed detection of subtle changes in enzyme activity that would not be possible with the standard guaiacol substrate assay for peroxidase, which requires $100 \mathrm{ng}$ of enzyme for oxidation. 


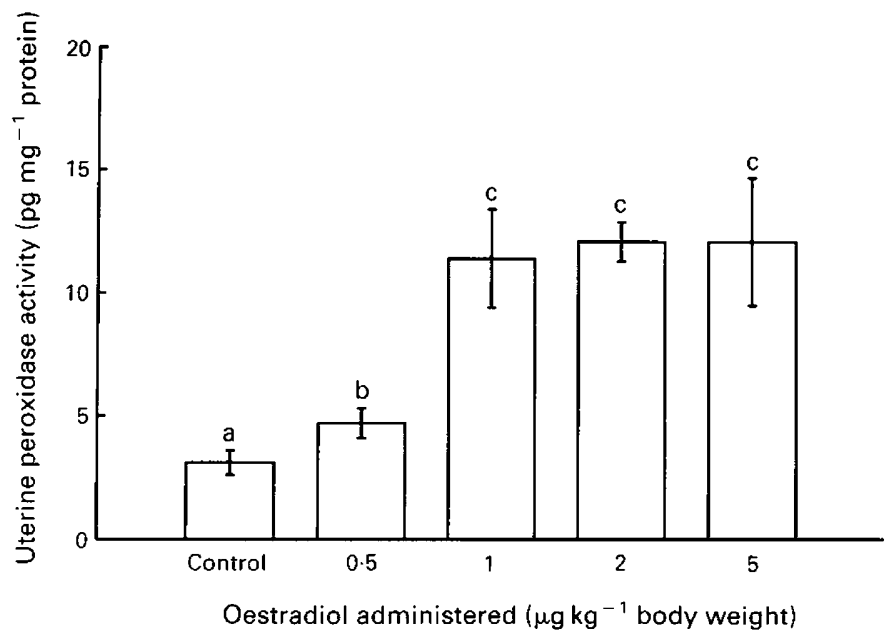

Fig. 4. Peroxidase activity determined by $o$-phenylenediamine in calcium chloride extracts of individual uteri of immature rats injected (i.v.) with vehicle $(n=6)$ or the indicated quantity of oestradiol $(n=6)$, a,b,c Means $( \pm$ SEM) with different letters are significantly different $(P<0.05)$.

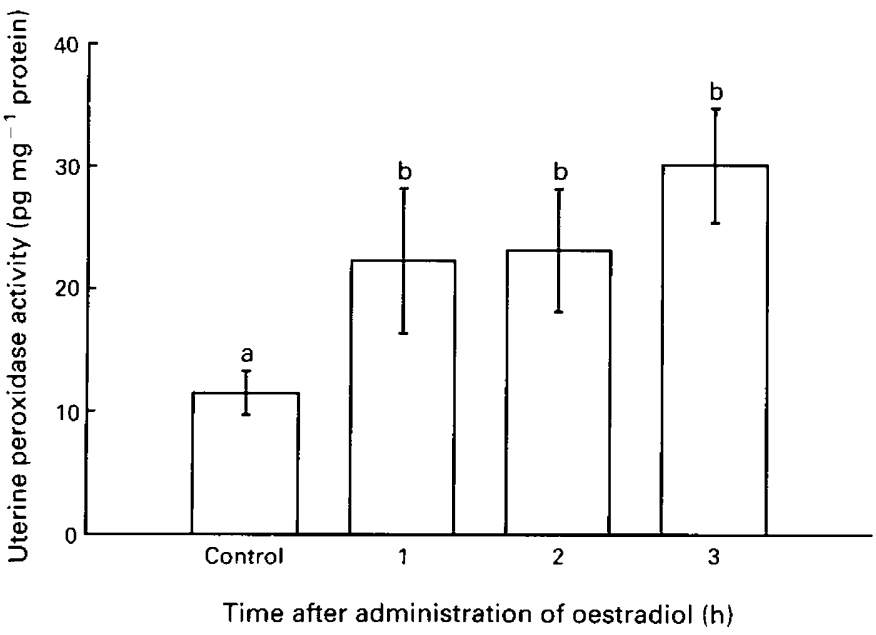

Fig. 5. Peroxidase activity determined by $o$-phenylenediamine in calcium chloride extracts of individual uteri of immature rats killed at three time points (six animals per time point) after s.c. administration of $100 \mu \mathrm{g} \mathrm{kg}^{-1}$ body weight oestradiol. Control represents average peroxidase activity obtained from 18 animals (six per time point) after vehicle injection. a,b Means $( \pm$ SEM) with different letters are significantly different $(P<0.05)$.

The dose-response study showed that uterine peroxidase activity is positively correlated with the early vascular response to oestradiol administration, namely, uterine hyperaemia. It appears that the dose-response range is very narrow $2 \mathrm{~h}$ after oestrogen administration when uterine hyperaemia is the dominant oestrogen response. This observation, together with the finding that increases in uterine peroxidase precede increases in uterine blood volume (Figs 3 and 5), suggests that a change in peroxidase activity is involved in the initiation of uterine vasodilation and that, once underway, enzyme activity does not continue to increase during the hyperaemic response. 


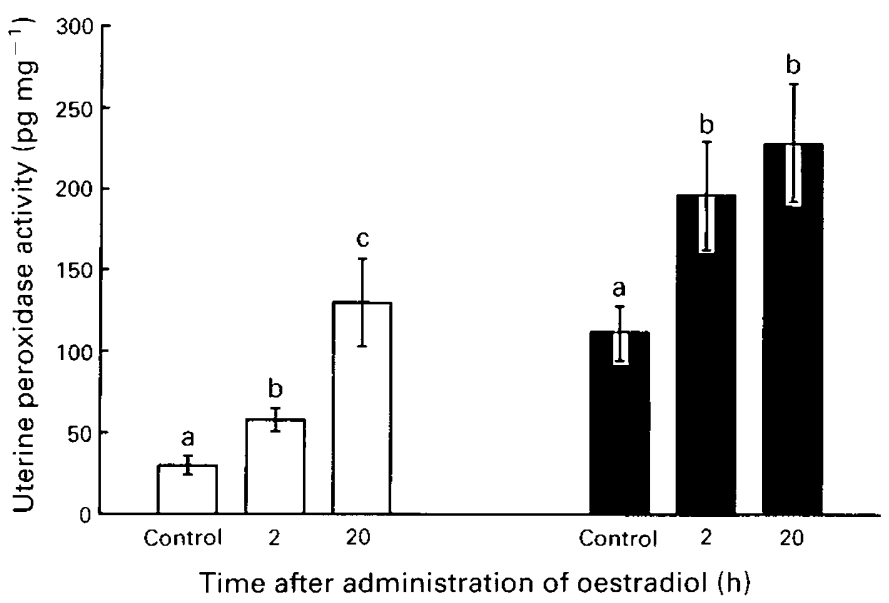

Fig. 6. Peroxidase activity determined by $o$-phenylenediamine in the calcium chloride-extracted fraction $(\square)$ and the soluble fraction ( $\square$ ) of uterine homogenate pools prepared from immature rats injected with oestradiol, $100 \mu \mathrm{g} \mathrm{kg}^{-1}$ body weight and killed at $2 \mathrm{~h}(n=11)$ or $20 \mathrm{~h}$ $(n=11)$. Control group $(n=13)$ injected with vehicle and killed at $20 \mathrm{~h}$. Within a fraction, pool values with different letters are significantly different $(P<0.05)$.

The biological importance of an early rise in peroxidase activity after oestrogen exposure may be a critical link in the development of uterine hyperaemia. Catechol oestrogens not only dilate the uterine artery in vivo but are also the only oestrogen compounds that are effective in vitro as well (Stice et al., 1987). Thus it has been suggested that catechol oestrogens may be the mediators of the vascular effects of oestrogen. We showed that the metabolism of oestrogens by uterine peroxidase yields catechol oestrogens (Rosazza et al., 1989) and that uterine arteries can synthesize catechol oestrogens from the parent oestrogens (Van Orden et al., 1983). In addition, these hydroxylated oestrogens may have a negative feedback effect on peroxidase by behaving like suicide inhibitors of the enzyme that synthesizes them (Rosazza et al., 1989). Oestrogen has been reported to inactivate uterine peroxidase; this suggests a role for this enzyme in many diverse events such as cell detoxification, bactericidal action and hormone recycling (Klebanoff, 1965; Brokelman, 1969; Jellinck et al., 1979). From previous and present data, a sequence of events after administration of oestrogen may be: increased peroxidase activity, hydroxylation of oestrogen, vasodilation and subsequent inactivation of the synthesizing enzyme, peroxidase.

The origin of the uterine peroxidase that is increased soon after administration of low dose oestrogen is unknown. In studies using long-term exposure to oestrogen ( $>24 \mathrm{~h}$ ), it has been shown that peroxidase may come from two distinct sources: endogenous uterine tissue peroxidase and eosinophil-derived peroxidase (Tchernitchin et al., 1974; King et al., 1981). Although Olsen \& Little (1982) suggest that these two enzymes are identical (on the basis of range of similar properties), others have presented cytochemical and biochemical evidence that distinguishes the endogenous and the exogenous or eosinophil peroxidases. Anderson et al. (1986) noted that as many as 15 peroxidase isoforms are expressed at successive stages after stimulation of the uterus with oestrogen.

Since the immature rat has a very poorly developed uterine epithelium, it appears more likely that the peroxidase activity measured very soon after exposure to a low dose of oestrogen could be from eosinophils. Lyttle's group (Lee et al., 1989) has recently proposed that oestrogen regulation of eosinophil peroxidase occurs by a uterine chemotactic factor (ECF-U), the synthesis of which is mediated by the oestradiol receptor. Although they report that the maximum increase was not observed until $24 \mathrm{~h}$, there was a significant increase in ECF-U activity $3 \mathrm{~h}$ after injection of $1 \mu \mathrm{g}$ oestradiol. Peroxidase activity, as measured by the $o$-phenylenediamine assay in the current study, was significantly increased $1 \mathrm{~h}$ after oestrogen injection (Fig. 5); this may indicate that the very early 
response $(1-3 \mathrm{~h})$ either precedes the elaboration of the chemotactic protein, or that the detection limits of the chemotaxis assay prevent the measurement of earlier increases in activity. Eosinophils have been shown to increase in number within $5 \mathrm{~min}$ of oestrogen administration (Tchernitchin et al., 1974) but the number of cells required to provide a measurable quantity of peroxidase will depend on the sensitivity of the enzyme assay used.

The administration of oestrogen to immature rats resulted in unexpectedly high peroxidase activity ( $>200 \mathrm{pg} \mathrm{mg}^{-1}$ protein) in the soluble fraction of uterine homogenates (Fig. 6). Others, using the guaiacol assay, have shown little (4.3\%) or no activity in the uterine soluble fraction (Hosoya \& Saito, 1981) or the hypotonic supernatant fraction (Lyttle \& DeSombre, 1977) obtained from oestrogen-treated rats. The differences between these observations and those reported in the present study may be explained by detection limits (o-phenylenediamine assay is 1000 -fold more sensitive than guaiacol) or substrate specificities or by both. Peroxidase activity was also present in a soluble fraction from uterine tissue when an alternative substrate, 4-aminoantipyrine, was used as the hydrogen donor (authors' unpublished data). Lymphatic fluid from the uterus of pregnant pigs, assayed using $o$-phenylenediamine, was found to contain large quantities $\left(>5 \mathrm{ng} \mathrm{ml}^{-1}\right)$ of peroxidase activity (authors' unpublished data). Hosoya \& Saito (1981) reported large quantities of a uterine fluid peroxidase that has a molecular weight twice that of uterine tissue peroxidase, a different $\mathrm{CM}$-cellulose chromatography elution profile and electrophoretic properties that are rather different from those of uterine tissue peroxidase. Furthermore, Gabriel et al. (1986) have combined cytochemical, immunocytochemical and autoradiographic studies to show that oestrogen induces the synthesis and secretion of numerous peroxidase isozymes found in the uterine fluid.

In conclusion, quantitative measurements of uterine blood volume and uterine peroxidase activity using the sensitive $o$-phenylenediamine assay provide evidence, for the first time, that levels of peroxidase are directly correlated with the extent of uterine hyperaemia, the early vascular response to exposure to oestrogen. Activity of soluble peroxidase is also high in the uterus during oestrogen hyperaemia and this warrants further study concerning its characteristics and the potential for conversion of oestrogens to vasoactive catechol oestrogen.

The authors thank E. Rus for technical assistance and L. Lammer for preparation of the manuscript.

\section{References}

Anderson, W.A., Kang, Y.H. \& DeSombre, E.R. (1975) Endogenous-peroxidase, specific marker enzyme for tissue displaying growth dependency on estrogen. Journal of Cell Biology 64, 668-681.

Anderson, W.A., Gabriel, B.W., Nerurkar, S.G., Wyche, J.H., Yates, P.E. \& Hanker, J.S. (1986) Peroxidases induced in rat uterus by estrogen administration. II. Cytochemical and biochemical heterogeneity. Journal of Submicroscopic Cytology 18, 683-690.

Ball, P. \& Knuppen, R. (1990) Formation, metabolism, and physiologic importance of catecholestrogens. American Journal of Obstetrics and Gynecology 163, 2163-2170.

Brokelmann, J. (1969) Peroxidase-associated binding of estradiol by the rat uterus. Journal of Histochemistry and Cytochemistry 17, 394-407.

DeSombre, E.R. (1984) Peroxidase: a marker for estrogen expression. In Biochemical Actions of Hormones (Vol. XI), pp. 309--344. Ed. G. Litwack. Academic Press, New York.

Ford, S.P. (1989) Factors controlling uterine blood flow during estrus and early pregnancy. In The Uterine
Circulation, pp. 113-134. Ed. C. R. Rosenfeld. Perinatology Press, New York.

Gabriel, B.W., Eckberg, W.R., Wyche, J.H., Meones, H., Hanker, J.S. \& Anderson, W.A. (1986) Peroxidases induced in rat uterus by estrogen administration. I. Synthesis, secretion and immunofluorescent demonstration of fluid enzymes. Journal of Submicroscopic Cytology 18, 673-682.

Gallati, V.H. \& Brodbeck, H. (1982) Peroxidase aus Meerrettich: Kinetische studien und optimierung der aktivitatsbestimmung mit den substraten $\mathrm{H}_{2} \mathrm{O}_{2}$ und $o$-phenylendiamin. Journal of Clinical Chemistry and Clinical Biochemistry 20, 221-225.

Hosoya, T. \& Saito, T. (198I) Comparative studies on estrogen-dependent peroxidases contained in uterine microsomes and fluid of rats and pigs. Journal of Biochemistry 89, 203-215.

Jellinck, P.H. \& Lyttle, C.R. (1972) Estrogen induced uterine enzymes in the control of estradiol action. Advances in Enzyme Regulation 11, 17-33.

Jellinck, P.H. \& Newcombe, A.M. (1980) Effect of catechol estrogens and estriol on the induction of uterine 
peroxidase. Journal of Steroid Biochemistry 13, 681-683.

Jellinck, P.H., Newcombe, A. \& Keeping, H.S. (1979) Peroxidase as a marker enzyme in estrogen-responsive tissues. In Advances in Enzyme Regulation (Vol. 7), pp. 325-343. Ed. G. Weber. Pergamon, New York.

Jellinck, P.H., Perry, M., Lovsted, J. \& Newcombe, A.M. (1985) Metabolism of estradiol by true and pseudoperoxidases. Steroid Biochemistry 22, 699-704.

King, W.J., Allen, T.C. \& DeSombre, E.R. (1981) Localization of uterine peroxidase activity in estrogentreated rats. Biology of Reproduction 25, 859-870.

Klebanoff, S.J. (1965) Inactivation of estrogen by rat uterine preparations. Endocrinology 76, 301-311.

Klebanoff, S.J. \& Smith, D.C. (1970) Peroxidasemediated antimicrobial activity of rat uterine fluid. Gynecology Investigations 1, 21-30.

Lee, Y.H., Howe, R.S., Sha, S.-J., Teuscher, C., Sheehan, D.M. \& Lyttle, C.R. (1989) Estrogen regulation of an eosinophil chemotactic factor in the immature rat uterus. Endocrinology 125, 3022-3028.

Lucas, F.V., Neufeld, H.A., Ulterback, J.G., Martin, A.P. \& Stotz, E. (1955) The effect of estrogen on the production of a peroxidase in the rat uterus. Journal of Biological Chemistry 214, 755-780.

Lyttle, C.R. \& DeSombre, E.R. (1977) Uterine peroxidase as a marker for estrogen action. Proceedings of the National Academy of Sciences USA 74, 3162-3166.

Lyttle, C.R. \& Jellinck, P. (1976) Subcellular localization of oestrogen-induced uterine peroxidase. Biochemical Journal 160, 237-241.

Lyttle, C.R., Teuscher, C., Medlock, K.L. \& Sheehan, D.M. (1989) Estradiol-stimulated increases in uterine eosinophils and nuclear type II estrogen-binding sites are prevented by pertussis toxin. Endocrinology 125, 2773-2779.

Mondschein, J.S., Hersey, R.M. \& Weisz, J. (1986) Purification and characterization of estrogen-2/4hydroxylase activity from rabbit hypothalami: peroxidase-mediated catechol estrogen formation. Endocrinology 119, 1105-1112.

Olsen, R.L. \& Little, C. (1982) Comparative studies on oestrogen-induced rat uterus peroxidase and rat eosinophil peroxidase. Biochemical Journal 207, 613-616.

Rosazza, J.P.N., Sanchez, C.M., Williamson, J., Van Orden, D.E. \& Markham, A. (1989) Biocatalysis and catechol estrogens. Developments in Industrial Microbiology 30, 173-183.

Stice, S.L., Ford, S.P., Rosazza, J.P. \& Van Orden, D.E. (1987) Role of 4-hydroxylated estradiol in reducing $\mathrm{Ca}^{2+}$ uptake of uterine arterial smooth muscle cells through potential sensitive channels. Biology of Reproduction 36, 361-368.

Tchernitchin, A., Roorijck, J., Tchernitchin, X., Vandenhende, J. \& Galand, P. (1974) Dramatic early increase in uterine eosinophils after oestrogen administration. Nature 248, 142-143.

Van Orden, D.E., Farley, D.B., Rosazza, J.P. \& Ford, S.P. (1986) Synthesis of catecholestrogens by the uterus. Society for Gynecological Investigations 33, 385.

Van Orden, D.E., Clancey, C.J., Van Orden, C.L. \& Ford, S.P. (1983) Synthesis of catechol estrogen by porcine uterine arteries. Proceedings of the Endocrinology Society p. 302 (Abstract).

Received 17 April 1991 